\title{
Design and implementation of an ecological cooler
}

\section{Diseño e implementación de un enfriador ecológico}

\author{
MOLINA-GARCÍA, Moisés $\dagger^{*} \&$ MELCHOR-HERNÁNDEZ, Cesar L.
}

Tecnológico Nacional de México. Instituto Tecnológico Superior de Huatusco, Av. 25 Poniente No. 100, Col. Reserva Territorial Huatusco, Veracruz, México, C.P. 94100, División de Ingeniería Electromecánica.

ID $1^{\text {st }}$ Author: Moises, Molina-Garcia / ORC ID: 0000-0002-4213-9591, CVU CONACYT ID: 311075.

ID $1^{\text {st }}$ Co-author: Cesar L, Melchor-Hernández / ORC ID: 0000-0003-2154-6654, Researcher Thomson ID: AAU - 3494 - 2021, CVU CONACYT ID: 161766

DOI: $10.35429 / J I D .2021 .12 .5 .48 .51$

Received March 23, 2021; Accepted June 30, 2021

\begin{abstract}
This work shows the construction of an ecological cooler capable of fulfilling the functions of a conventional refrigerator, its operation is based on using Peltier cells which create cold on one side and heat on the other. It is about eliminating the use of refrigerant gases, which damage the ozone layer, in addition to oils and accessories that are harmful to the environment, electrical energy is also saved with the prototype. The construction of the prototype is based on the construction of a panel that has 2 Peltier cells, 3 fans and a radiator system, which is integrated into a cooling drawer, the system is connected to a direct current voltage source. The prototype is designed to be used as a cooling system to contain food mainly, in addition to completely eliminating the refrigerants and mechanical components that are used in conventional refrigeration, which cause contamination of the ozone layer and the environment.
\end{abstract}

Peltier cells, Savings, Environment

\begin{abstract}
Resumen
El presente trabajo muestra la construcción un enfriador ecológico capaz de cumplir con las funciones de un refrigerador convencional, su funcionamiento se basa en utilizar celdas Peltier las cuales crean frio de un lado y calor del otro. Se trata de eliminar el uso de gases refrigerantes, los cuales dañan la capa de ozono, además de aceites y accesorios que son perjudiciales para el medio ambiente, también se ahorra energía eléctrica con el prototipo. La construcción del prototipo se basa en construcción de un panel que cuenta con 2 celdas Peltier, 3 ventiladores y un sistema de radiador, el cual va integrado a un cajón de enfriamiento, el sistema esta conectado a una fuente de voltaje de corriente directa. El prototipo esta diseñado para ser utilizado como un sistema de enfriamiento para contener alimentos principalmente, además de eliminar por completo los refrigerantes y componentes mecánicos que son utilizados en la refrigeración convencional, causantes de contaminar la capa de ozono y el medio ambiente.
\end{abstract}

Celdas Peltier, Ahorro, Medio ambiente

Citation: MOLINA-GARCÍA, Moisés \& MELCHOR-HERNÁNDEZ, Cesar L. Design and implementation of an ecological cooler. Journal Innovative Design. 2021, 5-12: 48-51

\footnotetext{
*Correspondence to the Author (e-mail: mmolinag@ @uatusco.tecnm.mx)

$\dagger$ Researcher contributing as first author.
} 


\section{Introduction}

Sustainable energy is providing energy that meets the needs of the present without compromising the needs of future generations. Sustainable energy sources include all renewable energies, including also technologies designed to improve energy efficiency. [III].

For the development of the cooler it must be known that it is a Peltier cell and its operation, knowing its properties allows us to know which is the most appropriate to put the cooler into operation since there is a wide range of cells on the market, but each one with a different application according to its cooling capacity, energy consumption, dimensions, voltages, heat capacity, among others.

The Peltier effect consists in that when a current is passed through a circuit composed of different materials whose junctions are at the same temperature, the inverse effect of the Seebeck effect occurs. [I] In this case, heat is absorbed in one joint and is released in the other, the part that cools is usually close to $25^{\circ}$ $\mathrm{C}$, while the part that absorbs heat can quickly reach $80^{\circ} \mathrm{C}$, all according to the cooling system connections, it is a system that allows the temperature level to lower and cool.

In the transport of biological samples, containers with 3 cells have been used, which allows reaching a temperature of $0{ }^{\circ} \mathrm{C}$; Most materials can be obtained from automotive coolers, fridges, and water coolers. [IV].

For vaccine cooling, 2 cells are generally used, consuming approximately 25 Watts. [V].

With the prototype, the use of refrigerant gases that cause damage to the ozone layer is being eliminated, as well as the use of compressors and oils that damage the environment. The development of the prototype is presented, explaining the parts that comprise it, in materials and methods, the connections that must be made to have the complete system are explained and finally the tests that were made are shown, when connecting the prototype and observing its operation.

\section{Developing}

For the creation, implementation and development of the ecological cooler, it was decided to connect 2 Peltier cells that are the ones that provide us with the necessary cooling capacity, the dimensions are similar to that of a conventional minibar, the measurements are 50 $\mathrm{cm}$ long by $40 \mathrm{~cm}$ wide, leaving a space in the container of $200 \mathrm{~cm}^{3}$, as the number of cells increases, its cooling capacity increases and consequently the size. Three axial fans, two external and one internal, are those that disperse the cold from the cells to which a heat sink is connected, which is an instrument used to lower the temperature of some electronic components. A voltage source of 12 Volts that provides us with a current of 20 Amps.

\section{Methodology to be developed}

The material inside is food grade 304 stainless steel sheet, once the cooler's shape is created, the 2 cells are installed, which are connected together with a cooling system as a whole, which It consists of 1 heat sink, 2 external radiators connected to a $1 / 2$ "copper tube, 3 fans, one of 3" and the other two of 5". The Peltier cells are of the TECI-12715 model since they are the ones that reach the lowest temperatures according to the comparison with another cell model when performing the tests. The system must be connected to a source that generates 12 Volts with a current capacity of 20 Amps, so that the system can cool as quickly as possible.

\section{Heat dissipator}

The function of a heat sink is to keep the hot part of the cells on the outside as cold as possible, maintaining a heat transfer from the inside to the outside, while the other heat sink that goes through the inside together with the The fan is responsible for dispersing the temperature constantly.

Aluminum air heatsinks are an option to take into account since they are great heat sinks, it should be noted that these components are made up of a fan together with an aluminum heatsink that comes with copper tubes for being better heat conductors. . The operation is ultimately the same as the series, but these are characterized by having a greater power. [II] 
Su funcionamiento se basa en la ley cero de la termodinámica, transfiriendo el calor de la parte caliente que se desea disipar al aire. [VI]. The internal cooling system consists of 1 aluminum panel model 536343, measuring $31 \frac{1}{2}$ "long by 3 " wide and $1 \frac{1}{2}$ "high, and the external part also consists of 1 aluminum panel model 536393 , with measures of $101 / 2$ "long by $6 \frac{1}{2}$ " wide and $1 / 2$ " high.

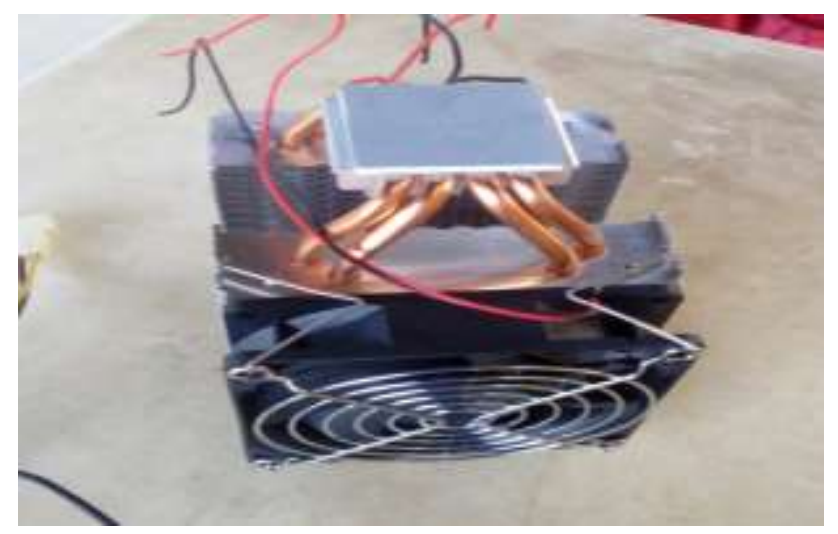

Figure 1 Heat sink installed on the outside

\section{Drawer insulation}

Polyurethane of the pressurized type in a can with a capacity of $300 \mathrm{ml}$ was used. The polyurethane aerosol foam has a class B3 component according to DIN 4102, which serves to seal and fill large gaps, preventing the passage of heat from the interior to the exterior or vice versa. This was an insolation type finish that it takes care of in all cooling and temperature insulation processes. The density of the foam is 225 to $35 \mathrm{~kg} / \mathrm{m}^{3}$, the temperature resistance ranges from $-55{ }^{\circ} \mathrm{C}$ to $100^{\circ} \mathrm{C}$, the thermal conductivity is $0.63 \mathrm{~W} / \mathrm{m}$ $\mathrm{K}$ ( $\mathrm{R}$ value $=4-5$ per inch) and the expansion Thermal of the can is from $300 \mathrm{ml}$ to $18 \mathrm{lt}$.

\section{Fans}

The fans used correspond to the common ones of a normal desktop computer, these are responsible for ensuring that the heat sink does not overheat, but in turn will have the function of releasing or removing little of the heat generated by the cells. 3 axial fans were installed, 2 of 5 "wide and 1 of $21 / 2$ " wide, its model is AD0812MS-A70GL, they work with direct current at 12 Volts and their consumption is $0.5 \mathrm{~A}$.

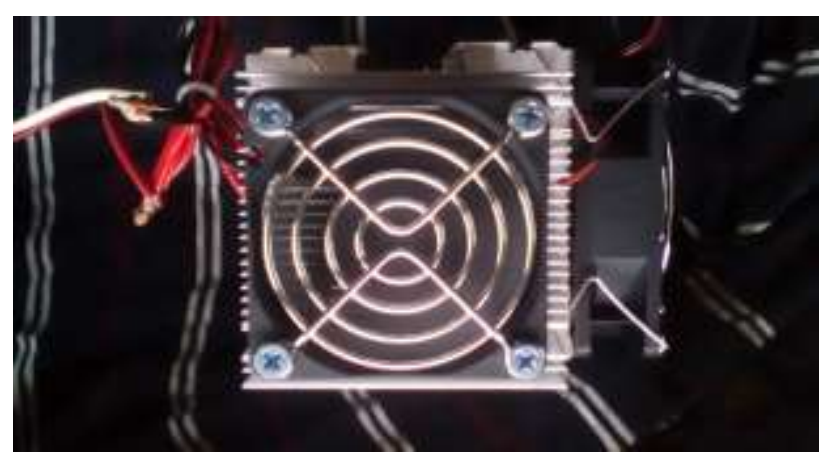

Figure 2 Axial fans

\section{Results}

When starting the tests, the external ambient temperature must be taken into account, preferably having the cooler at an ambient temperature no higher than $25^{\circ} \mathrm{C}$. The voltage should be 12 Volts and the current should be as close to $20 \mathrm{~A}$ as possible, to have the highest possible performance. Once these conditions were met, the results were the following:

\begin{tabular}{|l|r|r|r|c|r|}
\hline \multicolumn{1}{|c|}{ Weather } & \multicolumn{1}{c}{ Temp. } & \multicolumn{1}{c|}{ Temp. } & \multicolumn{1}{c|}{ V } & Consumption \\
\hline 0 min. & $23^{\circ} \mathrm{C}$ & $20^{\circ} \mathrm{C}$ & $12 \mathrm{~V}$. & $20 \mathrm{~A}$. & $0.8 \mathrm{~A}$. \\
\hline $15 \mathrm{~min}$. & $23^{\circ} \mathrm{C}$ & $18^{\circ} \mathrm{C}$ & $12 \mathrm{~V}$. & $20 \mathrm{~A}$. & $0.8 \mathrm{~A}$ \\
\hline 30 min. & $24^{\circ} \mathrm{C}$ & $17^{\circ} \mathrm{C}$ & $12 \mathrm{~V}$. & $20 \mathrm{~A}$. & $0.8 \mathrm{~A}$. \\
\hline 1 hora & $24^{\circ} \mathrm{C}$ & $15^{\circ} \mathrm{C}$ & $12 \mathrm{~V}$. & $20 \mathrm{~A}$. & $0.8 \mathrm{~A}$. \\
\hline 2 horas & $25^{\circ} \mathrm{C}$ & $15^{\circ} \mathrm{C}$ & $12 \mathrm{~V}$. & $20 \mathrm{~A}$. & $0.8 \mathrm{~A}$. \\
\hline 3 horas & $25^{\circ} \mathrm{C}$ & $15^{\circ} \mathrm{C}$ & $11.35 \mathrm{~V}$. & $20 \mathrm{~A}$. & $0.76 \mathrm{~A}$. \\
\hline 4 horas & $24^{\circ} \mathrm{C}$ & $14^{\circ} \mathrm{C}$ & $11.19 \mathrm{~V}$. & $20 \mathrm{~A}$. & $0.73 \mathrm{~A}$. \\
\hline 5 horas & $22^{\circ} \mathrm{C}$ & $14^{\circ} \mathrm{C}$ & $11.62 \mathrm{~V}$. & $20 \mathrm{~A}$. & $0.78 \mathrm{~A}$. \\
\hline 6 horas & $21^{\circ} \mathrm{C}$ & $12^{\circ} \mathrm{C}$ & $12 \mathrm{~V}$. & $20 \mathrm{~A}$. & $0.8 \mathrm{~A}$. \\
\hline 7 horas & $20^{\circ} \mathrm{C}$ & $10^{\circ} \mathrm{C}$ & $12 \mathrm{~V}$. & $20 \mathrm{~A}$. & $0.8 \mathrm{~A}$. \\
\hline 8 horas & $20^{\circ} \mathrm{C}$ & $9^{\circ} \mathrm{C}$ & $12 \mathrm{~V}$. & $20 \mathrm{~A}$. & $0.8 \mathrm{~A}$. \\
\hline 9 horas & $20^{\circ} \mathrm{C}$ & $9^{\circ} \mathrm{C}$ & $12 \mathrm{~V}$. & $20 \mathrm{~A}$. & $0.8 \mathrm{~A}$. \\
\hline 10 horas & $19^{\circ} \mathrm{C}$ & $9^{\circ} \mathrm{C}$ & $12 \mathrm{~V}$. & $20 \mathrm{~A}$. & $0.8 \mathrm{~A}$. \\
\hline 11 horas & $17^{\circ} \mathrm{C}$ & $9^{\circ} \mathrm{C}$ & $12 \mathrm{~V}$. & $20 \mathrm{~A}$. & $0.8 \mathrm{~A}$. \\
\hline 12 horas & $17^{\circ} \mathrm{C}$ & $9^{\circ} \mathrm{C}$ & $12 \mathrm{~V}$. & $20 \mathrm{~A}$. & $0.8 \mathrm{~A}$. \\
\hline
\end{tabular}

Table 1 Results obtained

The internal temperature of the cooler continued to be read for up to 12 hours, it was recorded that the temperature no longer dropped more than $9{ }^{\circ} \mathrm{C}$ and remained constant.

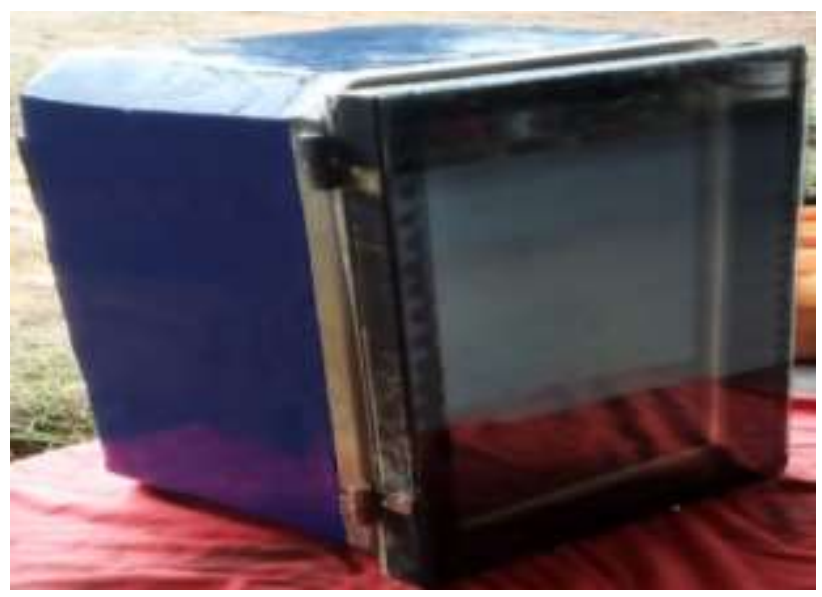

Figure 3 Final structure of the prototype

MOLINA-GARCÍA, Moisés \& MELCHOR-HERNÁNDEZ, Cesar L. Design and implementation of an ecological cooler. Journal Innovative Design. 2021 


\section{Appreciation}

We thank the Tecnológico Nacional de México, especially the campus: Instituto Tecnológico Superior de Huatusco, for funding for the presentation of the article. To the Department of Electromechanical Engineering for the facilities provided.

To MELCHOR-HERNÁNDEZ, Cesar $\mathrm{L}$. $\mathrm{PhD}$ for structuring the article.

To BERNARDI-CRIVELLI, Gino Rafael, for his contribution in the assembly of the prototype.

\section{Conclusions}

The energy consumption during the entire cooling process is 0.8 amps at its maximum working point, which is an excessively low consumption compared to the frigobars that are on the market, they have a consumption of 5 to 5.3 Amps at their point. maximum. Using this prototype of ecological cooler there is an energy saving of up to 6 times compared to the normal ones, this shows that to reach a consumption similar to the home refrigerator we would have to use 6 Peltier cells to be almost on par with normal consumption. Energy is saved by using the ecological cooler, in addition to taking care of the environment by not having an equipment that uses refrigerant gas, or oils and compressors.

\section{References}

[I] G, P. (05 de 12 de 2017). Peltier effect. Buenos Aires, Buenos Aires, Argentina.

[II] Méndez, A. (11 de 01 de 2016). Heat sinks for electronic devices. Barcelona, Cataluña, España.

[III] Moreno, D. R. (04 de 03 de 2018). Introduction to renewable energy systems. Monterrey, Nuevo León, México.

[IV] Ochoa, S. A. (05 de 01 de 2014). Institutional Repository UNISON. Recuperado el 03 de 12 de 2020, de http://www.repositorioinstitucional.uson.mx/ha ndle/unison/1730

[V] Vaca, L. F. (23 de 11 de 2016). Institutional Digital Repository of the National Polytechnic
School. Recuperado el 03 de 08 de 2020, de https://bibdigital.epn.edu.ec/bitstream/15000/16 901/1/CD-7481.pdf

[VI] Yunus A. Cengel, M. A. (2011). Thermodynamics. New York: Mc Graw Hill. 